\title{
LEGAL FRAMEWORK FOR STRATEGIC AND CRITICAL INFRASTRUCTURE
}

\author{
Natalia Kidalova \\ Assistant at the Department of International Law and Comparative Law, \\ National University of Life and Environmental Sciences of Ukraine, Ukraine \\ e-mail: yurdinasty@gmail.com,orcid.org/0000-0001-5681-508X
}

\section{Summary}

Causing damage to objects of strategic and critical infrastructure affects the security of the state. Economic and environmental consequences may result in human casualties, financial losses, etc. Accordingly, proper protection of objects of strategic and critical infrastructure at the legislative level is of great importance.

There is a need to identify objects of strategic and critical infrastructure and to address issues related to the protection of their infrastructures. Legislation must contain comprehensive definition of objects of strategic and critical infrastructure. This definition must include criteria and procedure of inclusion of facilities in the critical and strategic infrastructure.

In order to ensure the protection of critical infrastructure and facilities of strategic importance to the economy and security of the state it is necessary to create legal basis for its comprehensive protection against external encroachment and implement foreign experience in this sphere. There is a need to create legislation and methodological materials, taking into account foreign experience.

Keywords: strategic enterprises, critical infrastructure, state security, privatization.

DOI: https://doi.org/10.23856/4522

\section{Introduction}

Nowadays there is the need to create an appropriate infrastructure, the operation of which would be aimed at the smooth operation of enterprises, institutions and organizations that are classified as objects of critical or strategic importance for the economy and security of the state. However, in the presence of imperfect legislation, there is a danger of omission of enterprises that are truly critical and of strategic importance for the security of the state from the list of objects of critical and strategic infrastructure. Accordingly, proper regulation is not the last among the issues that require legal analysis and research.

So, taking into account the aforesaid, the purpose of this article is to analyze legal regulation of objects of critical and strategic infrastructure in Ukraine and make recommendations for improving existing legislature.

\section{Protection of strategic enterprises}

In the United States, critical infrastructure includes systems, networks and individual facilities, the disruption or destruction of which can cause huge or even irreversible negative consequences for the economy, welfare and health of the population, the stable course of political processes (Department of Justice or the USA, 2020).

The concept of critical infrastructure protection is also implemented in such developed countries as Canada, Australia, Great Britain. It should be noted that in most of them the 
identification of objects of critical infrastructure is carried out in accordance with the approved methods for assessing threats and risks to its sustainable operation.

In the National Security Strategy of Ukraine, ensuring information security, cyber security and security of information resources and critical infrastructure are identified as priorities of the state (Prezydent Ukrainy, 2015).

However, in the legislation of Ukraine the protection of objects, which according to the world practice belong to the sector of critical infrastructure, is regulated by numerous normative-legal acts, which are predominantly of a departmental nature (Ministerstvo ekonomichnogho rozvytku Ukrainy, 2015).

For further development of the protection system, O. Melnychuk proposed the development of legal, organizational, methodological, technological and other tools for the protection of critical infrastructure, depending on the level of risks, components of the infrastructure: element - the smallest component of the infrastructure that can be identified (wagon); - object functionally related collection of elements (rolling stock); - segment - a set of objects (railway station); - sector - a group of segments (a separate subdivision of the railway); - infrastructure - a complete set of similar sectors and processes (railway infrastructure). It is also advisable to take into account objects of related infrastructures (Melnychuk, 2019: 14).

\section{Objects of critical and strategic infrastructures and features of their status}

To the objects of critical infrastructure in Ukrainebelong enterprises and institutions (regardless of ownership) of industries, such as energy, chemical industry, transport, banks, information technology and telecommunications (electronic communications), food industry, health industry, which are strategically important for the functioning of the economy and security of the state, society and population, the decommissioning or destruction of which may affect national security and defense, the environment, lead to significant material and financial damage, human casualties (Kabinet Ministriv Ukrainy, 2016).

The Law of Ukraine "On Basic Principles of Ensuring Cyber Security of Ukraine" uses the term "objects of infrastructure of critical importance", defining them as legal entities which activities are directly related to technological processes and / or provision of services of great importance to the economy and industry, functioning of society and security of the population, disruption of which may have a negative impact on the national security and defense of Ukraine, the environment, cause damage to property and / or pose a threat to human life and health. This Law also provides an interrelated definition of the object of critical information infrastructure: a communication or technological system of object of critical infrastructure, the cyber attack of which will directly affect the sustainable operation of such object of critical infrastructure. This Law also provides an interrelated definition of the object of critical information infrastructure (Verkhovna Rada Ukrainy, 2017).

The list of state-owned objects of strategic importance for the economy and security of the state is approved by the Resolution of the Cabinet of Ministers of Ukraine of March 4, 2015 № 83. This Resolution providesforthe approval of the list of state-owned objects of strategic importance for the economy and security of the state.Ministries, other subjects of state property management have to systematically review the list approved by this Resolution and submit, if necessary, by July 10 of each year to the Ministry of Economic Development and Trade substantiated proposals for each object.The Cabinet of Ministers of Ukraine makes a decision to amend the list. The list includes the following objects:enterprises of the defense industry; oil companies, enterprises of energy, metallurgical, chemical, agro-industrial complexes; objects 
of transport industry; enterprises providing placement and storage of material assets of the state reserve; machine-building, food industry, aviation, rocket and space industries; scientific, hydrometeorological activities; spheres of standardization, metrology and certification; financial and budgetary sphere and printing industry (Kabinet Ministriv Ukrainy, 2015).

Objects of state property that are of strategic importance for the economy and security of the state include economic entities of the public sector of the economy (hereinafter - enterprises) that meet one or more criteria defined in the Resolution of the Cabinet of Ministers of Ukraine "On determining the criteria for classification of state property to those that are of strategic importance for the economy and security of the state" of November 3, 2010.

An enterprise is of strategic importance for the economy and security of the state if the share of its products in the market of relevant goods in Ukraine is not less than 20 percent (Kabinet Ministriv Ukrainy, 2010).

Peculiarities of the status of strategic objects are defined by the Law of Ukraine of 21.09.2006 № 185-V "On management of state property", according to which the Cabinet of Ministers of Ukraine:

- approves the decisions of the authorized governing bodies on the creation, reorganization and liquidation of public sector enterprises that are of strategic importance for the economy and security of the state;

- approves the list of state-owned objects of strategic importance for the economy and security of the state (paragraphs 22 and 24 of the second part of Article 5 of the Law);

- creates economic organizations on the basis of objects of state property that are of strategic importance for the economy and security of the state (part 8 of article 11 of the Law);

- votes on an additional issue of shares by a representative of the state at a general meeting of economic organizations of strategic importance for the economy and security of the state, in the authorized capital of which the corporate rights of the state exceed 10 percent (Verkhovna Rada Ukrainy, 2006).

The list of state-owned objects of strategic importance for the economy and security of the state is approved by the Cabinet of Ministers of Ukraine in accordance with the Law of Ukraine "On Management of State-Owned Objects".

\section{Subjects of strategic importance}

Strategic entities include public sector entities that meet one or more criteria. Entities of the public sector of the economy are entities operating on the basis of state ownership, as well as entities which state share in the authorized capital exceeds fifty percent, is a value that provides the state with a decisive influence on economic activities of these entities (Verkhovna Rada Ukrainy, 2003).

In accordance with the requirements of the Procedure for submission and consideration of proposals for the formation of the list of state property that is of strategic importance for the economy and security of the state, proposals for inclusion (exclusion) of objects in the list are submitted by the authorized management body signed by its head with the relevant justifications for each enterprise separately. Justifications for inclusion (exclusion) of objects in the list should contain information of the authorized management body on compliance (non-compliance) of enterprises with the criteria and information on the impact of enterprises on the activities of enterprises of the relevant economy, industry as a whole and enterprises of other sectors. The procedure defines the list of documents provided by the Ministry of Economic Development to the authorized management body to confirm the compliance (non-compliance) 
of the enterprise with the criteria. In case of non-compliance of the received proposals with the requirements of the Procedure, the Ministry of Economic Development notifies the authorized management body in writing within a month of the refusal to make the proposed changes to the list (Ministerstvo ekonomiky Ukrainy, 2010).

Maintaining the vital functions of society, protection of basic needs of its members and creation of a sense of security in them is a basic condition for ensuring national sustainability. Therefore, ensuring the security and sustainability of objects of critical infrastructure is defined as a basic element of ensuring national sustainability (Sukhodolia, 2015: 51).

Taking into account the information set forth in the aforesaid normative legal acts, it is not the obligation of enterprises to provide reliable information that can be traced, but rather the procedural process of proving on their part that they are strategically important for the state, which often does not correspond to the interests of the managers of these facilities.

\section{Conclusions}

Although objects of critical and strategic infrastructure are in the same plane of perception, their legal regulation is carried out by various legislative norms in Ukraine.Therefore, there is a need to create a comprehensive definition of objects of strategic and critical infrastructure. This definition must include criteria and procedure of inclusion of facilities in the critical and strategic infrastructure.Legislation should guarantee the safe operation of objects of critical infrastructure.

For safe operation of objects of critical infrastructure it is necessary: to create legal basis for comprehensive protection against encroachments of different nature; provide for legal liability as a measure for a quick response to the influence of an illegal nature; implement international experience in this area.

\section{References}

Department of Justice or the USA. Uniting and strengthening America by providing appropriate tools required to intercept and obstruct terrorism (PATRIOT ACT): Retrieved from:http:// frwebgate.access.gpo.gov(accessed 17.09.2020).

Keruvannia ryzykom. Metody zahalnoho ocinuvannia ryzyku (IEC/ISO 31010:2009, IDT): DSTUIEC/ISO 31010:2013. [Risk management. General risk assessment methods (IEC / ISO 31010: 2009, IDT): DSTU IEC / ISO 31010:2013]. (2014, June 1). Kyiv: Ministerstvoekonomichnoho rozvytku Ukrainy. [in Ukrainian].

Melnychuk O.S.(2019). Upravlinnja krytychnoju infrastrukturoju derzhavy: bazovi metody ta kryteriji identyfikaciji ob'jektiv [Management of critical infrastructure of the state: basic methods and criteria for object identification]. Derzhavne upravlinnja ta misceve samovrjaduvannja [Public Administration and Local Self-Government] (electronic journal), no 3 (42), pp. 13-27. Retrieved from: http://www.dridu.dp.ua/zbirnik_dums/2019/2019_03(42)/4.pdf [in Ukrainian] (accessed 17.09.2020).

Nakaz Ministerstva Ekonomiky Ukrainy Pro porjadok podannja ta rozghljadu propozycij shhodo formuvannja pereliku ob'jektiv derzhavnoji vlasnosti, shho majutj strateghichne znachennja dlja ekonomiky $i$ bezpeky derzhavy [Order of the Ministry of Economy of Ukraine on procedure for submission and consideration of proposals for the formation of the list of state-owned objects of strategic importance for the economy and security of the state]. (2010, March 12). 
Vidomosti Verkhovnoi Rady Ukrainy - Bulletin of Verkhovna Rada of Ukraine. Kyiv: Parlam. vyd-vo [in Ukrainian].

Postanova Kabinetu Ministriv Ukrainy Pro porjadok formuvannja pereliku informacijno-telekomunikacijnykh system ob'jektiv krytychnoji infrastruktury derzhavy [Resolution of the Cabinet of Ministers of Ukraine on the order of formation of the list of information and telecommunication systems of objects of critical infrastructure of the state]. (2016, August 23). Vidomosti Verkhovnoi Rady Ukrainy - Bulletin of Verkhovna Rada of Ukraine. Kyiv: Parlam. vyd-vo [in Ukrainian].

PostanovaKabinetuMinistrivUkrainyPro vyznachennja kryterijiv vidnesennja ob'jektiv derzhavnoji vlasnosti do takykh, shho majutj strateghichne znachennja dlja ekonomiky i bezpeky derzhavy [Resolution of the Cabinet of Ministers of Ukraine on determining the criteria for classifying state-owned objects as those of strategic importance for the economy and security of the state].(2010, November 3). Vidomosti Verkhovnoi Rady Ukrainy - Bulletin of Verkhovna Rada of Ukraine. Kyiv: Parlam. vyd-vo [in Ukrainian].

Postanova Kabinetu Ministriv Ukrainy Pro zatverdzhennja pereliku ob'jektiv derzhavnoji vlasnosti, shho majutj strateghichne znachennja dlja ekonomiky i bezpeky derzhavy [Resolution of the Cabinet of Ministers of Ukraine of on approval of the list of state-owned objects of strategic importance for the economy and security of the state]. (2015, March 4). Vidomosti Verkhovnoi Rady Ukrainy - Bulletin of Verkhovna Rada of Ukraine. Kyiv: Parlam. vyd-vo [in Ukrainian]. Sukhodolia O.M.(2017). Zakhyst krytychnoji infrastruktury: suchasni vyklyky ta priorytetni zavdannja sektoru bezpeky [Critical infrastructure protection: modern challenges and priority tasks of the security sector]. Naukovyj chasopys Akademiji nacionaljnoji bezpeky[Scientific journal of the Academy of National Security], no 1-2 (13-14), pp. 50-80 [in Ukrainian].

Ukaz Prezydenta Ukrainy Pro rishennja Rady nacionaljnojibezpeky i oborony UkrajinyPro StrateghijunacionaljnojibezpekyUkrajiny»/Decree of the President of Ukraine on the decision of the National Security and Defense Council of Ukraine on the National Security Strategy of Ukraine]. (2015, May 29). Vidomosti Verkhovnoi Rady Ukrainy - Bulletin of Verkhovna Rada of Ukraine. Kyiv: Parlam. vyd-vo [in Ukrainian].

Zakon Ukrainy Pro osnovni zasady zabezpechennja kiberbezpeky Ukrajiny/Law of Ukraine on the basic principles of cybersecurity in Ukraine]. (2017, October, 5). Vidomosti Verkhovnoi Rady Ukrainy - Bulletin of Verkhovna Rada of Ukraine. Kyiv: Parlam. vyd-vo [in Ukrainian]. ZakonUkrainyPro upravlinnja ob'jektamy derzhavnoji vlasnosti [Law of Ukraine on management of objects of state property]. (2006, September 21). Vidomosti Verkhovnoi Rady UkrainyBulletin of Verkhovna Rada of Ukraine. Kyiv: Parlam. vyd-vo [in Ukrainian].

Hospodarskyi kodeks Ukrainy [Commercial Code Ukraine]. (2003, January 16). Vidomosti Verkhovnoi Rady Ukrainy - Bulletin of Verkhovna Rada of Ukraine. Kyiv: Parlam. vyd-vo [in Ukrainian]. 